\title{
Acute human toxicity and mortality after selenium ingestion: A review
}

\author{
Hadrup, Niels; Ravn-Haren, Gitte
}

Published in:

Journal of Trace Elements in Medicine and Biology

Link to article, DOI:

10.1016/j.jtemb.2019.126435

Publication date:

2020

Document Version

Peer reviewed version

Link back to DTU Orbit

Citation (APA):

Hadrup, N., \& Ravn-Haren, G. (2020). Acute human toxicity and mortality after selenium ingestion: A review. Journal of Trace Elements in Medicine and Biology, 58, [126435]. https://doi.org/10.1016/j.jtemb.2019.126435

\section{General rights}

Copyright and moral rights for the publications made accessible in the public portal are retained by the authors and/or other copyright owners and it is a condition of accessing publications that users recognise and abide by the legal requirements associated with these rights.

- Users may download and print one copy of any publication from the public portal for the purpose of private study or research.

- You may not further distribute the material or use it for any profit-making activity or commercial gain

- You may freely distribute the URL identifying the publication in the public portal

If you believe that this document breaches copyright please contact us providing details, and we will remove access to the work immediately and investigate your claim 


\section{Acute human toxicity and mortality after selenium ingestion: a review}

Niels Hadrup ${ }^{\mathrm{a}^{*}}$ and Gitte Ravn-Haren ${ }^{\mathrm{b}}$

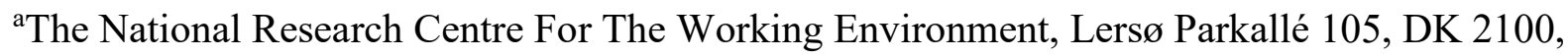

København Ø, Denmark, E-mail address N.H.: nih@nfa.dk ; ${ }^{b}$ National Food Institute, Technical

University of Denmark, Kemitorvet, DK 2800 Kgs. Lyngby, Denmark, E-mail address G.R.:

girh@food.dtu.dk

*Corresponding author, Niels Hadrup, The National Research Centre For The Working

Environment, Lersø Parkallé 105, DK 2100, København Ø, Denmark Telephone +4539165214; Email address: nih@,nfa.dk

Keywords: Se; selenate; selenite; selenium dioxide; gun bluing; toxic; acute poisoning 


\begin{abstract}
BACKGROUND: Although selenium is an essential element for humans, acute toxicity has been reported after high oral exposure.

METHODS: The published literature on the acute toxicity of oral selenium was gathered and reviewed.
\end{abstract}

RESULTS: Reported symptoms and signs include abdominal symptoms, such as vomiting, diarrhea, pain, and nausea, as well as garlic-like odor on the breath. In cases of severe toxicity, cardiac and pulmonary symptoms may develop and ultimately lead to mortality. Mortality has been described after the ingestion of gun bluing solutions, which often contain selenous acid among other potentially toxic substances. Mortality has also been reported after the ingestion of other forms of selenium. Ingested doses associated with mortality are in the range of 1 to $100 \mathrm{mg} \mathrm{Se} / \mathrm{kg}$ body weight. Blood levels associated with mortality are above $300 \mu \mathrm{g} \mathrm{Se} / \mathrm{L}$ (normal level: $100 \mu \mathrm{g} / \mathrm{L}$ ), whereas urinary levels associated with the same endpoint are above170 $\mu \mathrm{g} \mathrm{Se} / \mathrm{L}$ (normal level: 20 to $90 \mu \mathrm{g} / \mathrm{L})$.

CONCLUSION: The acute toxicity associated with oral selenium ingestion and the blood and urinary levels of selenium in different cases of poisonings were reviewed.. Mortality is a risk of acute selenium poisoning. Concentrations of selenium in blood and urine samples in non-fatal cases are close to those observed in fatal cases. 


\section{Introduction}

Selenium (Se) is an essential trace element that serves as a building block for the amino acids selenocysteine and selenomethionine. Yet at high levels, selenium is toxic, and several cases of overt toxicity and mortality have been reported following acute intoxication. We describe the acute toxic effects of selenium, including exposure, blood, and urine levels associated with mortality. When possible, we differentiate between different selenium formulations.

In order to obtain the relevant journal articles on the acute toxic effects of selenium, references were retrieved from the Pubmed [1] and SciFinder [2] databases, using a combination of the search terms: "selenium", "acute" and "toxicity". In addition, lists of references in relevant articles were evaluated, to identify additional publications that had not been obtained in the initial search. More than 300 article abstracts were evaluated. In total, 33 relevant articles presenting data on the acute toxicity of selenium in humans were included in the current review.

\section{Human mortality following selenium ingestion}

Figures 1 to 4 illustrate the doses of selenium and its blood and urinary levels in different forms associated with human mortality. The normal intake levels reported for selenium are between 11 and $280 \mu \mathrm{g} /$ day [3-7]. Plasma and blood levels in the general population lie around $100 \mu \mathrm{g}$ selenium/L [4,8-15]. The urinary concentration in healthy people range from 10 to $85 \mu \mathrm{g} / \mathrm{L}[16]$.

\section{Selenite}


A 75-year-old man ingested $10 \mathrm{~g}$ of sodium selenite $(\sim 66 \mathrm{mg} \mathrm{Se} / \mathrm{kg} \mathrm{bw}) .{ }^{1}$ He developed diarrhea, abdominal pain, hypotension, poor perfusion, prolonged electrocardiogram QT intervals, hypokalemia, and a serum selenium level of $68 \mu \mathrm{mol} / \mathrm{L}$ (equal to $5370 \mu \mathrm{g} \mathrm{Se} / \mathrm{L}$ ). He had cardiac arrest and died six hours after the ingestion [17,18]. Farago and Horvath [19] described a case of suicidal ingestion of sodium selenite. A 32-year old man ingested an unknown amount of sodium selenite and died 85 min after the ingestion after experiencing sweating, unconsciousness, pulmonary edema, cyanosis, and hurried respiration. His blood pressure was not palpable, fascicular convulsions occurred, and his selenium blood level was $500 \mu \mathrm{g} / \mathrm{L}$.

\section{Selenium dioxide}

A 17-year-old man attempted suicide by ingesting an unknown amount of selenium dioxide. Two hours later, he was admitted to the hospital in a comatose state with asystole and apnea, followed by death. The autopsy findings were congestion of the lungs and kidneys, diffuse swelling of the heart, brain edema, and an orange-brown discoloration of the skin and viscera. It was estimated that he had absorbed $10 \mathrm{~g}$ selenium ( $\sim 101 \mathrm{mg} \mathrm{Se} / \mathrm{kg} \mathrm{bw})$. The blood level of selenium was 38,000 $\mu \mathrm{g} / \mathrm{L}$, and high levels of selenium were observed in the pancreas $(1980 \mu \mathrm{g} / \mathrm{g})$, spleen $(1090 \mu \mathrm{g} / \mathrm{g})$, liver $(741 \mu \mathrm{g} / \mathrm{g})$, and gastric mucosa $(1516 \mu \mathrm{g} / \mathrm{g})[20]$.

Gun bluing agents - likely containing selenous acid

${ }^{1}$ In the current article a standard body weight (bw) of $70 \mathrm{~kg}$ is used for the calculation of doses in $\mathrm{mg} / \mathrm{kg}$ bw 
A 24-year-old man exhibited nausea, vomiting, and pulmonary edema. He lost consciousness and died from cardiopulmonary arrest three to four hours after the likely ingestion of gun bluing agent. One hour after the suspected ingestion, his selenium serum level was 30,000 $\mu \mathrm{g} / \mathrm{L}$. The postmortem blood concentration was $13,000 \mu \mathrm{g} \mathrm{Se} / \mathrm{L}$ [21].

A 54-year-old woman ingested 30 to $60 \mathrm{~mL}$ of liquid gun bluing agent. The dose was estimated to be 10 to $20 \mathrm{mg} / \mathrm{kg}$ of selenous acid ( $\sim 6$ to $12 \mathrm{mg} \mathrm{Se} / \mathrm{kg} \mathrm{bw}$ ). Symptoms included a garlic-like odor on the breath, hypotension, vasodilation, decreased cardiac output, adult respiratory distress syndrome, severe myopathy, respiratory failure, and death at eight days after the ingestion. Her serum selenium concentration was $2435 \mu \mathrm{g} / \mathrm{L}$ on day 4 and $2765 \mu \mathrm{g} / \mathrm{L}$ on day 5 , and her urinary selenium level was $2435 \mu \mathrm{g} / 24 \mathrm{~h}$ [22].

A 40-year-old woman ingested Super Blue gun bluing agent (an almost empty $90 \mathrm{~mL}$ bottle of Super Blue was found beside her). The gun bluing agent contained $4 \%$ selenous acid and $2.5 \%$ cupric sulfate in $1.7 \mathrm{~N} \mathrm{HCl}(62 \mathrm{~g} \mathrm{HCl} / \mathrm{L})(\sim 31 \mathrm{mg} \mathrm{Se} / \mathrm{kg}$ bw $)$. The patient experienced vomiting, diarrhea, and delusional stupor. She was confused and restless, her heart rate was 120 beats per minute, and her blood pressure was $102 / 66 \mathrm{mmHg}$, which decreased to $70 / 50 \mathrm{mmHg}$ at $4 \mathrm{~h}$ after admission. She had cardiac arrest and died $8 \mathrm{~h}$ after the ingestion. Autopsy findings included pulmonary edema with pleural effusion, congestion of the kidney, and necrosis of the kidney's proximal tubules. The selenium blood concentration was $2600 \mu \mathrm{g} / \mathrm{L}[23]$.

A 3-year-old boy likely ingested gun bluing agent and was admitted to the hospital with purposeless movements of the body and limbs. He had no response to painful stimuli and had sluggish pupillary light reflexes. His blood pressure and peripheral pulse rate were "un-recordable." The apex beat was impalpable, the heart rate was 120 beats per minute, and the respiratory rate was 24 breaths per minute. Salivation was excessive, and a strong smell of garlic or rotten onions was 
observed on the breath. His condition deteriorated rapidly with carpal spasm and increasing peripheral cyanosis, and he died 45 minutes after admission to the hospital. The autopsy revealed that the small intestine was dilated and moderately reddened. Upon chemical analysis, selenium and copper were found in gross quantities in the stomach. The estimated dose was $2.4 \mathrm{mg} / \mathrm{kg}$ bw/day ${ }^{2}$ [24].

A 22-month-old boy likely ingested $15 \mathrm{~mL}$ of gun bluing agent (containing selenous acid, among other chemicals). Initially, he was pink, alert, and combative, but his condition rapidly deteriorated. No measurable blood pressure was observed, and his oxygen saturation was only $84 \%$. His mental status deteriorated, he had to be ventilated by hand, and he became cyanotic, unresponsive, and without a palpable pulse. He developed ventricular fibrillation and died. Autopsy findings showed pulmonary congestion and a grayish creamy fluid in his stomach. The postmortem selenium blood level was $12,000 \mu \mathrm{g} / \mathrm{L}$, and the gastric content was $270 \mathrm{mg} \mathrm{Se} / \mathrm{L}$. It was estimated that he had ingested $93 \mathrm{mg} \mathrm{Se} / \mathrm{kg}$ bw [25].

Another 22-month-old boy ingested approximately $20 \mathrm{~mL}$ of gun bluing agent containing selenous acid at $2.8 \mathrm{~g}$ /ounce $\left(\sim 96 \mathrm{mg} \mathrm{Se} / \mathrm{kg} \mathrm{bw}^{3}\right)$, nitric acid at $1.4 \mathrm{~g} /$ ounce, and copper nitrate at 1.4 g/ounce. He had vomited shortly after ingestion, but his condition rapidly deteriorated, and he died 1.5 hours after ingestion [26]. A 2-year-old boy ingested $15 \mathrm{ml}$ of gun bluing agent and was hospitalized with a second-degree burn of both the esophagus and stomach. He became comatose, and mechanical ventilation was necessary. Metabolic acidosis, leukocytosis, hyperglycemia, and hemoconcentration were recorded. On the following day, severe intestinal distension, cardiomyopathy, moderate hepatic, and renal and pulmonary dysfunctions developed. The selenium

\footnotetext{
${ }^{2}$ At a body weight of $18 \mathrm{~kg}$

${ }^{3}$ At an estimated body weight of $12 \mathrm{~kg}$
} 
plasma concentration was $285 \mu \mathrm{g} / \mathrm{L}$, and maximum urinary concentration was $28,459 \mu \mathrm{g} \mathrm{Se} / \mathrm{L}$. After four days, his condition improved considerably, and he was about to be extubated when he suddenly developed acute respiratory distress. A similar episode occurred 24 hours later, his lung function progressively deteriorated, and he had to be ventilated using an extracorporeal membrane lung. He was found to be infected with Legionella dumofii and died 17 days after ingesting the gun bluing agent [27].

\section{Sodium tetraoxoselenate}

A 22-year-old woman ingested approximately $20 \mathrm{~mL}$ of sodium tetraoxoselenate of unknown concentration. She was hospitalized with vomiting, severe diarrhea, and abdominal pains. She developed cardiovascular failure and what was described as a strange smell emanating from her whole body. The dose was eventually fatal, and the autopsy findings included cerebral edema, focal fibromatosis of the heart, and massive congestion with focal hemorrhage in the lungs. The blood level of selenium at an unspecified sampling time was $1410 \mu \mathrm{g} \mathrm{Se} / \mathrm{L}[28,29]$.

\section{Selenium of unknown speciation}

In two cases of fatalities, selenium of unknown speciation was suspected as a poison. A 37-year-old woman and a 36-year-old man experienced nausea, vomiting, diarrhea, abdominal pain, muscle weakness, and pallor, which progressed to hypotension, pulmonary edema, and cardiovascular collapse. Autopsies showed hemorrhagic pulmonary edema and splenomegaly. The woman had a serum selenium concentration of $380 \mu \mathrm{g} / \mathrm{L}$, and the man had a blood level of $1900 \mu \mathrm{g} / \mathrm{L}$ [30]. 


\section{Summary}

The majority of the described fatal cases are associated with exposure to gun bluing agents, which often contains selenous acid. It cannot be excluded that other gun bluing ingredients played a role in these poisonings, but in most cases, high blood levels of selenium were reported. Mortality has also been described in single cases of sodium selenite, selenium dioxide, and sodium tetraoxoselenate poisonings. All of the forms of selenium described are inorganic, and as far as we know, no cases with mortality following acute exposure to organic selenium have been reported. Ingested doses associated with mortality are in the range of 1 to $100 \mathrm{mg} \mathrm{Se} / \mathrm{kg}$ bw and blood levels in most mortality cases were $1000 \mu \mathrm{g} \mathrm{Se} / \mathrm{L}$ or above (Figures $1-3$ ).

\section{Non-fatal human acute toxicity following the ingestion of selenium}

\section{Selenite}

A 56-year-old man ingested $1.7 \mathrm{~g}$ of sodium selenite $(\sim 11 \mathrm{mg} \mathrm{Se} / \mathrm{kg}$ bw $)$ and suffered from severe gastroenteritis. Three hours after the ingestion, his serum selenium concentration was $2716 \mu \mathrm{g} / \mathrm{L}$, which continually decreased over the next 153 hours to $91 \mu \mathrm{g} / \mathrm{L}$ [31]. A 23-year-old female consumed about $100 \mathrm{~mL}$ of liquid selenite broth and developed severe nausea, vomiting, abdominal pain, vomiting of blood, and renal failure. The blood level of selenium was $134 \mu \mathrm{g} / \mathrm{L}$. Eight weeks after being hospitalized, her renal function had completely recovered [32].

Five people ingested sodium selenite and developed nausea, diarrhea, abdominal pain, chills, and tremors shortly thereafter. All of the symptoms resolved within $24 \mathrm{~h}$. The initial serum selenium concentrations were between 410 and $890 \mu \mathrm{g} / \mathrm{L}$. The serum selenium concentration returned to normal within four days. The 24-h-urine selenium was between 1175 and $4363 \mu \mathrm{g}$ (587 
to $2180 \mu \mathrm{g} / \mathrm{L})^{4}$ [33]. A 15 -year-old girl intentionally swallowed $400 \mathrm{~mL}$ of sheep drench that bore the label "sodium selenite $5 \mathrm{mg} / \mathrm{mL}$." The precise selenium concentration in the liquid was determined to be $2.9 \mathrm{mg} / \mathrm{mL}$, and the estimated ingested dose $22.3 \mathrm{mg} \mathrm{Se} / \mathrm{kg} \mathrm{bw}$. The girl was made to vomit at both 20 and 45 minutes after the ingestion. Examination showed no remarkable signs except a strong odor of garlic on her breath and frequent loose grey feces. The initial serum level of selenium was $3100 \mu \mathrm{g} / \mathrm{L}$, and on the second day, the urinary selenium level was $680 \mu \mathrm{g} / \mathrm{L}$ [34].

\section{Selenium dioxide}

A 48-year-old woman had ingested $2000 \mathrm{mg}$ of selenium dioxide ( $20 \mathrm{mg} \mathrm{Se} / \mathrm{kg}$ bw/day). She had a garlic-like odor on the breath, as well as mucosal damage throughout the oral cavity, esophagus, and stomach, which was described as a deep gastric ulcer. The serum selenium level was 2400 $\mu \mathrm{g} / \mathrm{L}$, and the urinary selenium level was $1300 \mu \mathrm{g} / \mathrm{L}$. Following hemodialysis, both of these concentrations fell dramatically (600 and $700 \mu \mathrm{g} / \mathrm{L}$, respectively) [35].

\section{Gun bluing agents}

A two-year-old girl ingested an unknown amount of gun bluing agent. The amount was not exactly known, but $11 \mathrm{~mL}$ (corresponding to $2.9 \mathrm{~g}$ selenium) was missing from the bottle. With an estimated body weight of $12 \mathrm{~kg}$, this corresponds to $241 \mathrm{mg} \mathrm{Se} / \mathrm{kg}$ bw. She had hyper-salivation, vomiting, diarrhea, and increased blood pressure and pulse rate. Five hours after ingestion, the

${ }^{4}$ using a standard urine volume of $2 \mathrm{~L}$ 
plasma selenium concentration was 20 times higher than normal $(1600 \mu \mathrm{g} / \mathrm{L})$, and her urinary selenium level was $1340 \mu \mathrm{g} / \mathrm{L}$. The girl fully recovered [36].

\section{Selenic acid}

A 29-year-old man ingested a mouthful of selenic acid (30 g/L) corresponding with an estimated volume of $20 \mathrm{~mL}$ to $5 \mathrm{mg} \mathrm{Se} / \mathrm{kg}$ bw He suffered from mild gastrointestinal disturbances and transient electrocardiographic changes and had a strong garlic odor on the breath. The plasma concentration was $931 \mu \mathrm{g} \mathrm{Se} / \mathrm{L} 3 \mathrm{~h}$ after the ingestion of selenic acid, which continually decreased over the next 446 hours to $151 \mu \mathrm{g} / \mathrm{L}[31]$.

\section{Other sources of selenium}

A 51-year-old man and a 44-year-old woman had undergone a fasting treatment involving the daily ingestion of a supplement containing "selenium powder, magnesium powder, zinc drops, and a teaspoon of laxative salts." The selenium dosage was later observed to be 10 times higher than what was indicated in the treatment protocol. Severe diarrhea was recorded in the first days of treatment. A few days later, they suffered from nausea and a worsening general condition. The man developed headache, and both patients lost around $5 \mathrm{~kg}$ of bw. One to two days after finishing the treatment, considerable diffuse hair loss occurred, and white-brownish discolorations of the nails appeared. The serum levels of selenium were 347 and $387 \mu \mathrm{g} / \mathrm{L}$ for the woman and man, respectively. The gastrointestinal symptoms and headache diminished directly after discontinuation of the treatment, and four to five weeks later, complete detachment of all nails on the hands and feet was observed. Almost two months later, the growth of nails and hair restarted. Serum selenium levels returned to normal two months later [37]. 
Selenium was suspected of inducing acute toxicity in two women. They had ingested paradise nuts and subsequently developed dizziness, nausea, and vomiting lasting several days. In the first case, the serum level of selenium was $479 \mu \mathrm{g} / \mathrm{L}$ at eight weeks after ingestion. In the second case, the level was $300 \mu \mathrm{g} / \mathrm{L}$ at nine weeks after ingestion [38].

\section{Summary}

Several cases of selenite, selenium dioxide, and gun bluing agent intoxication were associated with abdominal signs and symptoms, and blood levels of up to approximately $3000 \mu \mathrm{g} \mathrm{Se} / \mathrm{L}$ have even been observed without mortality. A garlic-like odor on the breath was noted in several cases of selenium intoxication.

\section{Discussion of doses and blood levels associated with mortality}

Considering dose levels (Figure 1), it is observed that human doses of $10 \mathrm{mg} / \mathrm{kg}$ bw and above are associated with a risk of mortality. Notably, most human fatal cases are associated with the ingestion of gun bluing agents, which often contain selenous acid, as well as other potentially toxic chemicals. None of the cases of acute toxicity were associated with the ingestion of organic selenium in the form of selenocysteine or selenomethionine. This is partly explained by organic selenium being mostly present in food, from which one is not likely to obtain a dose leading to acute toxicity, but could also be explained by a lower toxicity of organic selenium. No differences could be determined for different inorganic selenium species, as there were not enough data to perform statistics on doses or blood levels (Figures 1 and 2). Selenium has a tolerable upper intake level of $300 \mu \mathrm{g} / \mathrm{day}$ set by EFSA ( 4 $\mu \mathrm{g} / \mathrm{kg}$ bw) [39] and a value of $400 \mu \mathrm{g} /$ day selenium $(\sim 6 \mu \mathrm{g} / \mathrm{kg}$ 
bw) set by the U.S. Food and Nutrition Board [40]. The toxicity levels described in this review (1 to $100 \mathrm{mg} / \mathrm{kg} \mathrm{bw}$ ) are more than 200 times higher, which provides an estimate of the gap between established tolerable chronic doses and acute toxic doses.

Blood and plasma levels of selenium increase dose-dependently to approximately $2000 \mu \mathrm{g} / \mathrm{L}$ at doses of up to approximately $25 \mathrm{mg} / \mathrm{kg}$ bw/day (Figure 2). One could argue that this is followed by a plateau effect, which perhaps reflects the body's attempts to maintain selenium blood levels at a safe level, such as by increasing the deposition or excretion rates. At doses of around 50 to $100 \mathrm{mg} / \mathrm{kg}$ bw the blood level of selenium seems to rise substantially, suggesting that compensatory mechanisms are overwhelmed (Figure 2). Figure 2 shows that the blood levels associated with mortality clearly overlap with the levels reported as having been ingested without causing mortality. A similar overlap is shown in Figure 3, which also includes studies in which the ingested dose is unknown. Yet despite this overlap, considering all the data points in Figures 2 and 3 together, it is observed that blood selenium levels of $1000 \mu \mathrm{g} / \mathrm{L}$ and above represent a high risk of mortality. Concerning urinary values (Figure 4), there is overlap between those in non-fatal cases and in fatal cases, although the data for cases associated with mortality are clearly limited with only three available data points.

\section{Summary}

Acute symptoms of selenium intoxication include abdominal symptoms such as vomiting, pain, and nausea, as well as garlic breath, and cardiac symptoms. Mortality has been described in several cases specifically following the ingestion of gun bluing agents, which contain selenous acid, but also with other inorganic forms of selenium. Mortality has been described in humans having 
ingested doses of 1 to $100 \mathrm{mg} \mathrm{Se} / \mathrm{kg}$ bw but equally high intakes have been reported in humans who did not die.

Mortality has been associated with blood/plasma levels between 300 and 30,000 $\mu \mathrm{g} / \mathrm{L}$ (normal level: $100 \mu \mathrm{g} / \mathrm{L})$. Nevertheless, there are also human cases of ingestion in which blood levels as high as $3000 \mu \mathrm{g} / \mathrm{L}$ are observed without mortality. Similarly, urinary levels of selenium associated with mortality are between 170 and $30,000 \mu \mathrm{g} / \mathrm{L}$ with urinary levels as high as $1000 \mu \mathrm{g} / \mathrm{L}$ in humans who did not die (normal level: 20 to $90 \mu \mathrm{g} / \mathrm{L}$ ). Concentrations of selenium in blood and urine samples in non-fatal cases are close to those observed in fatal cases.

\section{Conflicts of interest}

The authors declare that there are no conflicts of interest.

\section{Figure captions}


Lethal and non-lethal toxic doses of various forms of selenium

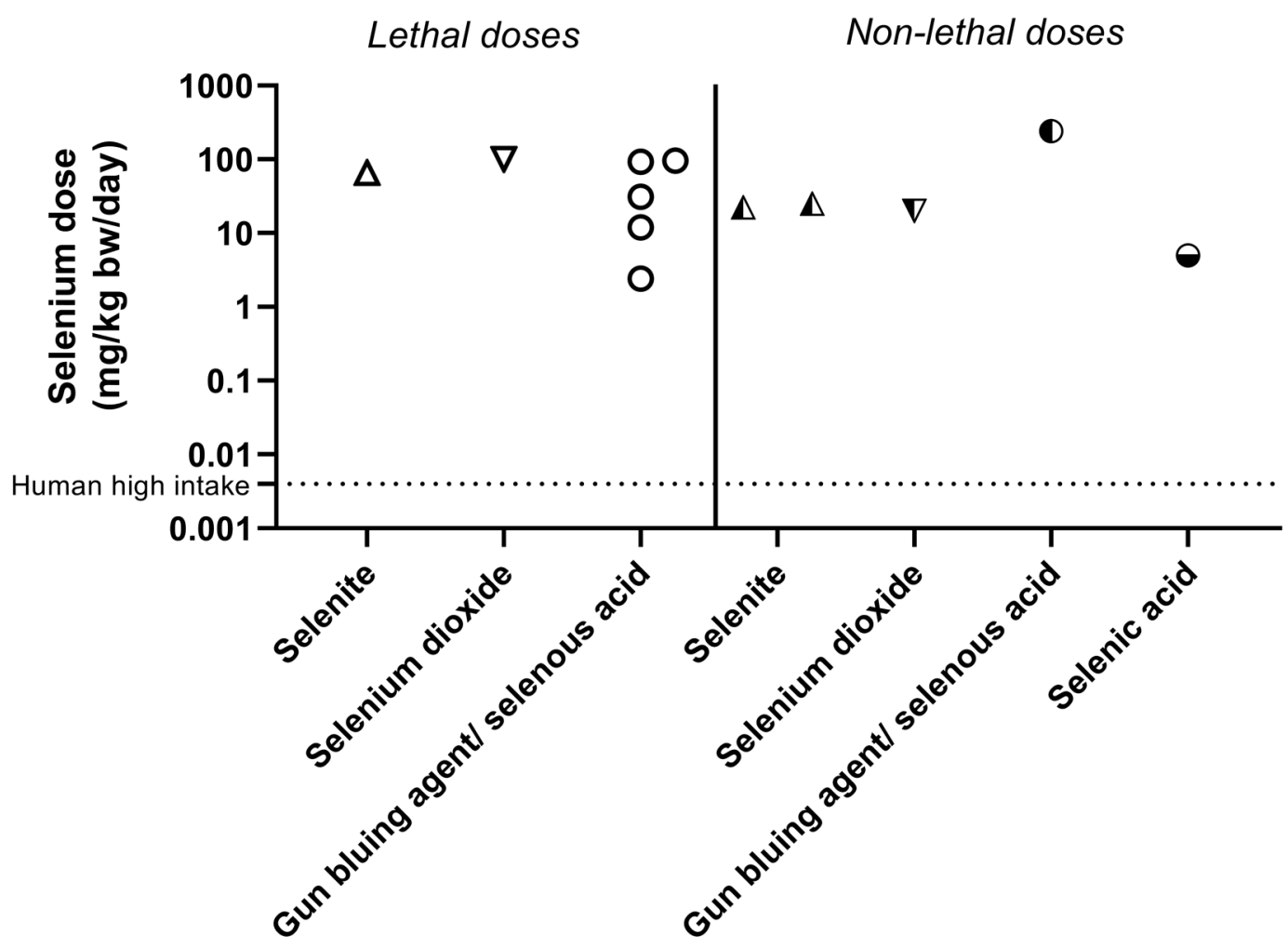

Figure 1. Fatal and non-fatal toxic doses of various forms of selenium. 


\section{Blood and plasma levels of selenium by dose}

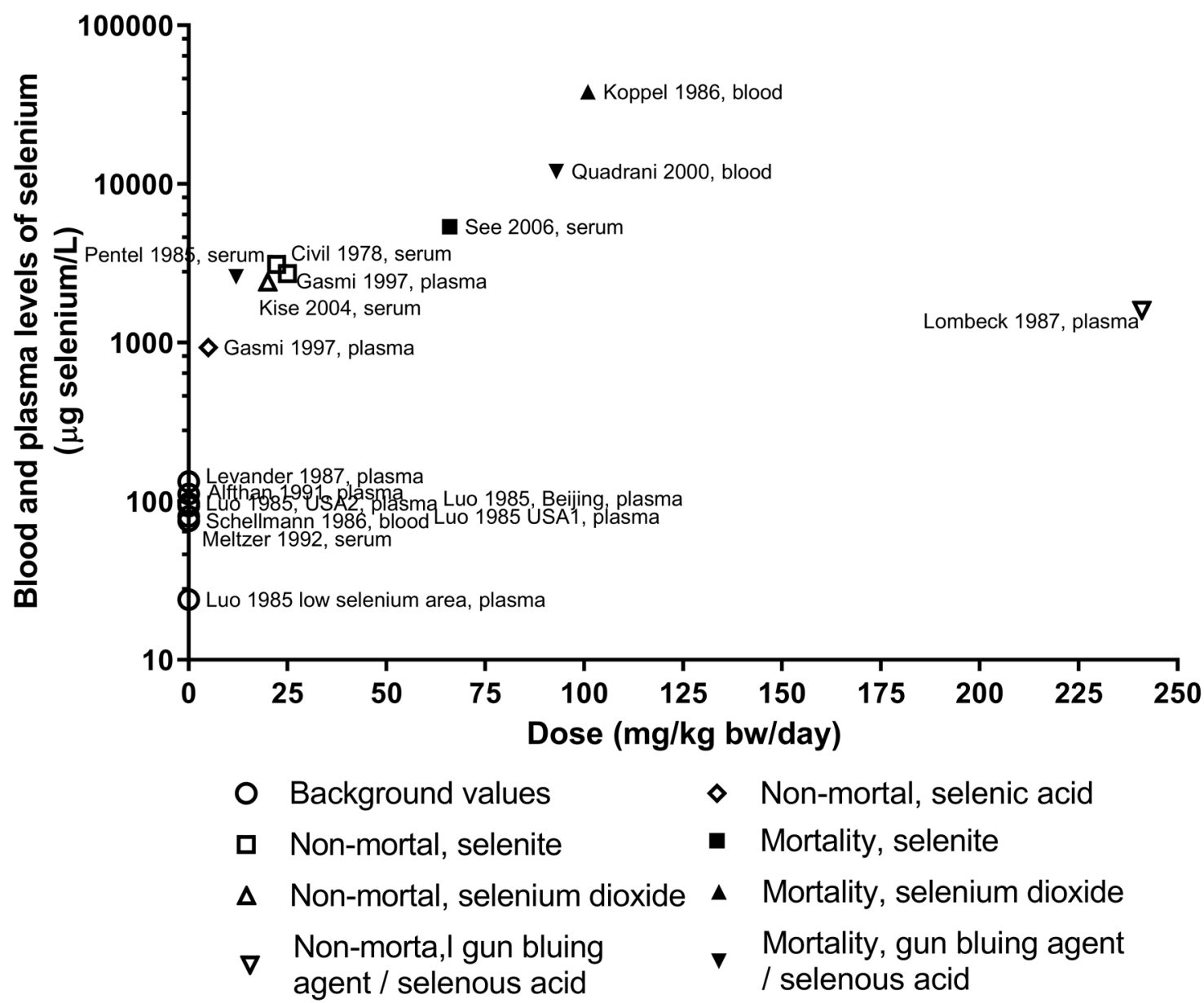

Figure 2. Human blood/plasma levels of selenium following acute selenium exposure. The datapoint of Lombeck et al. represents a very high estimated dose that was not associated with mortality. All data points are labeled with the first author of the specific report. "Blood" indicates blood concentration, "plasma" indicates plasma concentration, and "serum" indicates serum concentration. 


\section{Selenium blood/plasma levels}

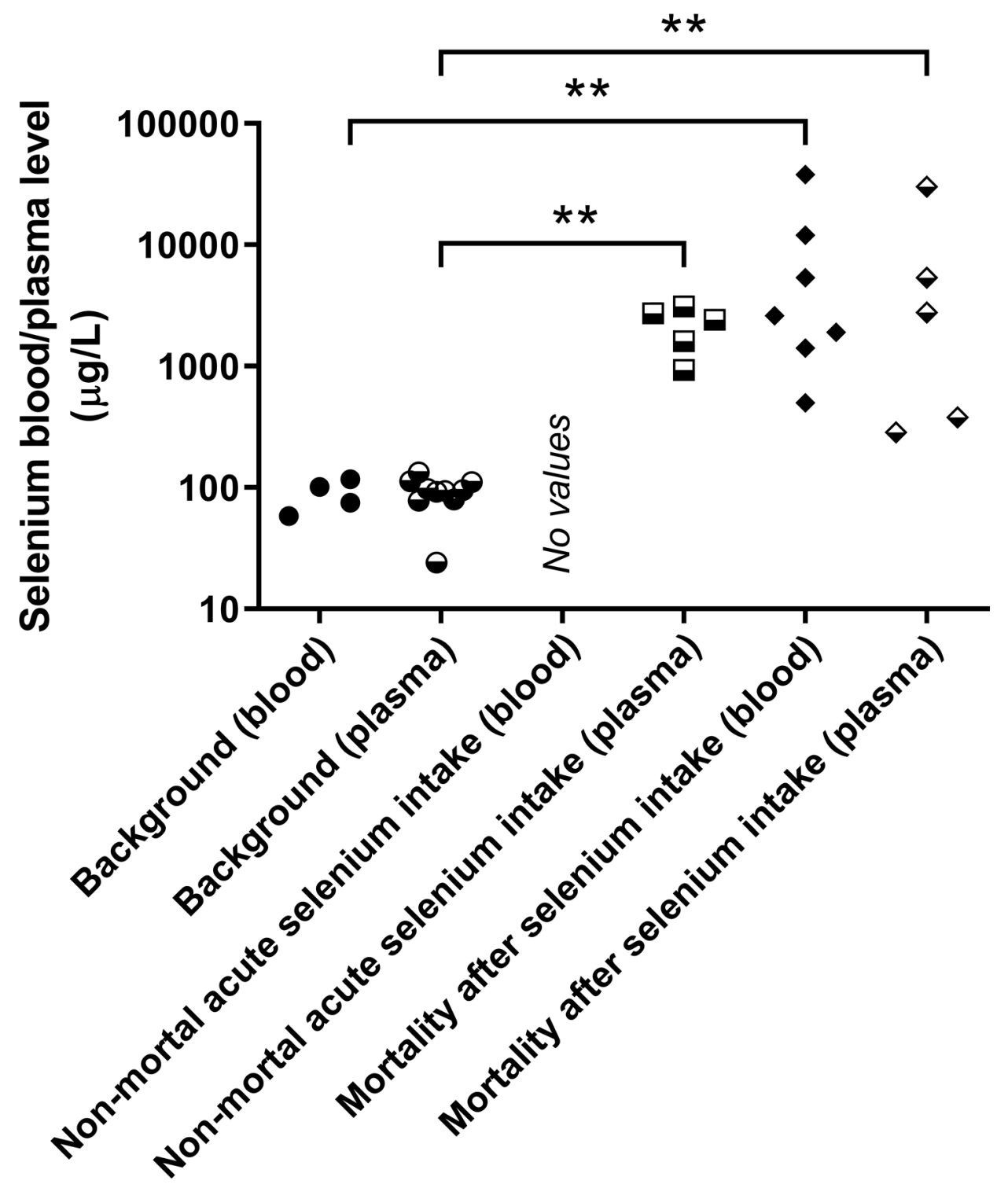

Figure 3. Human selenium blood/plasma levels associated with no selenium intake, and selenium intake in non-fatal and in fatal cases. Plasma and serum levels are both reported under "plasma." ** indicates a $p$-value of $<0.01$ vs. the background group according to the Kruskal-Wallis test with Dunn's multiple comparisons test (data in the fatal cases group were not normally distributed). For blood levels, $* *$ indicates a $p$-values of $<0.01$ according to the Mann-Whitney test. 
All tests were run using the software package Graph Pad Prism 7.02 (Graph Pad Software Inc., La Jolla, CA, USA).

\section{Urinary levels}

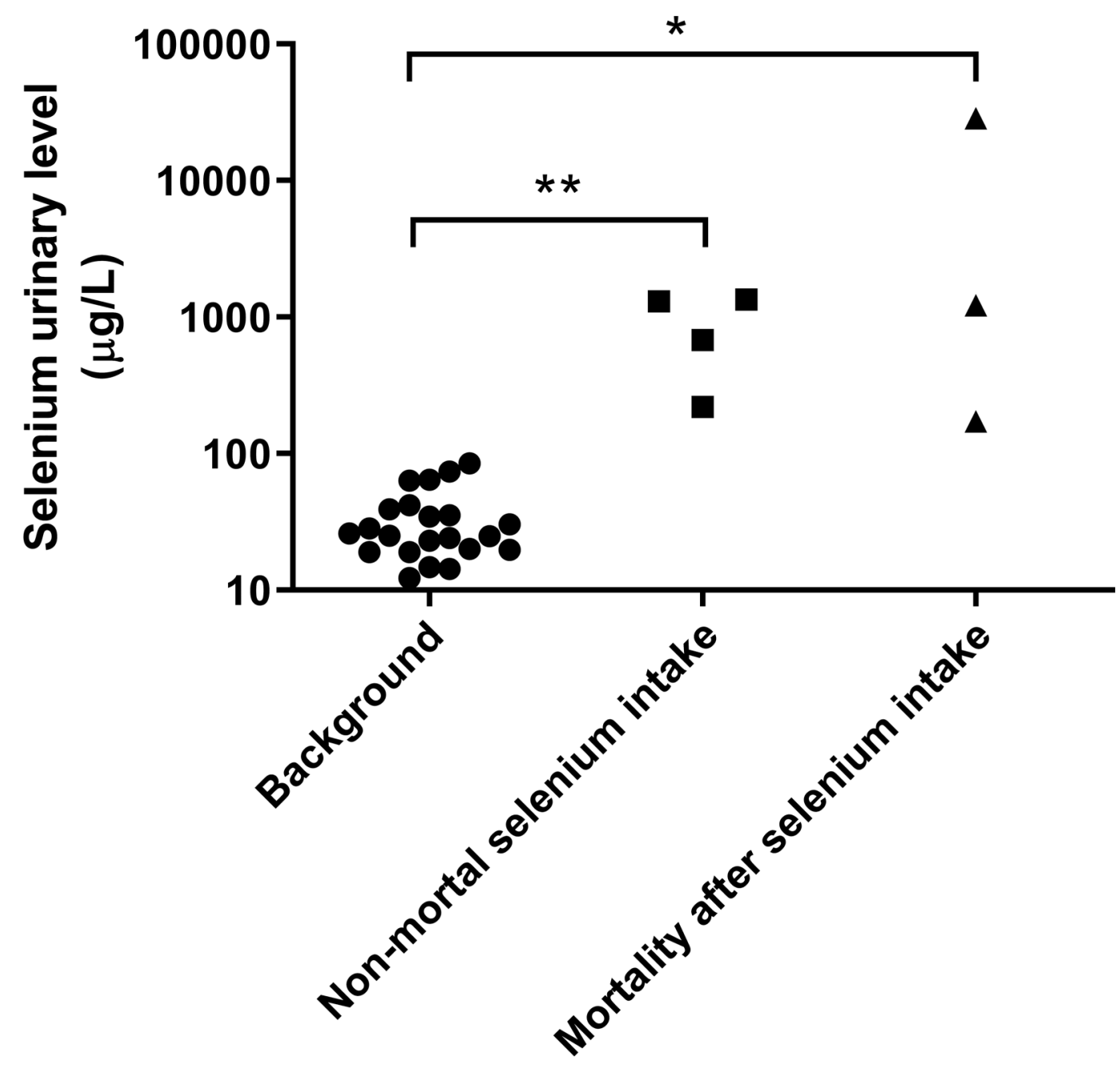

Figure 4. Human selenium urinary levels associated with no selenium intake, and selenium intake in non-fatal and in fatal cases. $* *$ and $*$ indicate $p$-values of $<0.01$ and $<0.05$, respectively, vs. the background group according to the Kruskal-Wallis test post-test and Dunn's multiple comparisons test (data in the fatal cases group were not normally distributed). The analyses were 
performed using the software package Graph Pad Prism 7.02 (Graph Pad Software Inc., La Jolla, CA, USA).

\section{References}

[1] Pubmed, Pubmed, (2019). www.pubmed.com (accessed June 1, 2019).

[2] CAS, Scifinder, (2019).

[3] O.A. Levander, V.C. Morris, Dietary selenium levels needed to maintain balance in North American adults consuming self-selected diets, Am. J. Clin. Nutr. 39 (1984) 809-815.

[4] O.A. Levander, P.B. Moser, V.C. Morris, Dietary selenium intake and selenium concentrations of plasma, erythrocytes, and breast milk in pregnant and postpartum lactating and nonlactating women, Am. J. Clin. Nutr. 46 (1987) 694-698.

[5] O.A. Levander, Clinical consequences of low selenium intake and its relationship to vitaminE, Ann. N. Y. Acad. Sci. 393 (1982) 70-82. https://doi.org/DOI 10.1111/j.17496632.1982.tb31233.x.

[6] R.S. Gibson, C.A. Scythes, Chromium, selenium, and other trace-element intakes of a selected sample of Canadian premenopausal women, Biol. Trace Elem. Res. 6 (1984) 105-116. https://doi.org/Doi 10.1007/Bf02916928.

[7] G.F. Clemente, L. Cignarossi, G.P. Santaroni, Trace-element intake and excretion in the Italian population, J. Radioanal. Chem. 37 (1977) 549-558. https://doi.org/Doi 10.1007/Bf02519367.

[8] X. Luo, H. Wei, C. Yang, J. Xing, C.H. Qiao, Y.M. Feng, J. Liu, Z. Liu, Q. Wu, Y.X. Liu, Selenium intake and metabolic balance of 10 men from a low selenium area of China, Am. J. Clin. Nutr. 42 (1985) 31-37. 
[9] G. Alfthan, A. Aro, H. Arvilommi, J.K. Huttunen, Selenium metabolism and platelet glutathione peroxidase activity in healthy Finnish men: Effects of selenium yeast, selenite, and selenate, Am. J. Clin. Nutr. 53 (1991) 120-125.

[10] H.M. Meltzer, G. Norheim, E.B. Løken, H. Holm, Supplementation with wheat selenium induces a dose-dependent response in serum and urine of a Se-replete population, Br. J. Nutr. 67 (1992) 287-294. https://doi.org/10.1079/BJN19920032.

[11] B. Schellmann, H.J. Raithel, K.H. Schaller, Acute fatal selenium poisoning. Toxicological and occupational medical aspects, Arch. Toxicol. 59 (1986) 61-3. http://www.ncbi.nlm.nih.gov/pubmed/3741146.

[12] E.Y. Gudmundsdottir, I. Gunnarsdottir, A. Thorlacius, O. Reykdal, H. Gunnlaugsdottir, I. Thorsdottir, L. Steingrimsdottir, Blood selenium levels and contribution of food groups to selenium intake in adolescent girls in Iceland, Food Nutr. Res. 56 (2012). https://doi.org/10.3402/fnr.v56i0.18476.

[13] B. Kłapcińska, S. Poprzecki, A. Danch, A. Sobczak, K. Kempa, Selenium levels in blood of upper Silesian population: evidence of suboptimal selenium status in a significant percentage of the population, Biol. Trace Elem. Res. 108 (2005) 1-15. https://doi.org/10.1385/BTER:108:1-3:001.

[14] G. Ravn-Haren, S. Bügel, B.N. Krath, T. Hoac, J. Stagsted, K. Jørgensen, J.R. Bresson, E.H. Larsen, L.O. Dragsted, A short-term intervention trial with selenate, selenium-enriched yeast and selenium-enriched milk: effects on oxidative defence regulation, Br. J. Nutr. 99 (2008) 883-892. https://doi.org/10.1017/S0007114507825153.

[15] G. Ravn-Haren, B.N. Krath, K. Overvad, S. Cold, S. Moesgaard, E.H. Larsen, L.O. Dragsted, Effect of long-term selenium yeast intervention on activity and gene expression of antioxidant 
and xenobiotic metabolising enzymes in healthy elderly volunteers from the Danish Prevention of Cancer by Intervention by Selenium (PRECISE) Pilot Study, Br. J. Nutr. 99 (2008) 11901198. https://doi.org/10.1017/S0007114507882948.

[16] M. Sanz Alaejos, C. Díaz Romero, Urinary selenium concentrations, Clin. Chem. 39 (1993) 2040-52. http://www.ncbi.nlm.nih.gov/pubmed/8403389.

[17] K.A. See, P.S. Lavercombe, J. Dillon, R. Ginsberg, Accidental death from acute selenium poisoning, Med. J. Aust. 185 (2006) 388-389.

[18] R. Williams, A. Ansford, Acute selenium toxicity: Australia's second fatality, Pathology 39 (2007) 289-90. https://doi.org/10.1080/00313020701230682.

[19] E. Farago, E. Horvath, Fatal, suicidal sodium selenite poisoning, Bull. Int. Assoc. Forensic Toxicol. 19 (1987) 30.

[20] C. Köppel, H. Baudisch, K.H. Beyer, I. Klöppel, V. Schneider, Fatal poisoning with selenium dioxide, J. Toxicol. Clin. Toxicol. 24 (1986) 21-35.

[21] D.M. Hunsaker, H.A. Spiller, D. Williams, Acute selenium poisoning: suicide by ingestion, J. Forensic Sci. 50 (2005) 942-946.

[22] P. Pentel, D. Fletcher, J. Jentzen, Fatal acute selenium toxicity, J. Forensic Sci. 30 (1985) 556562.

[23] R. Matoba, H. Kimura, E. Uchima, T. Abe, T. Yamada, Y. Mitsukuni, I. Shikata, An autopsy case of acute selenium (selenious acid) poisoning and selenium levels in human tissues, Forensic Sci. Int. 31 (1986) 87-92. https://doi.org/10.1016/0379-0738(86)90192-1.

[24] R.F. Carter, Acute selenium poisoning, Med. J. Aust. 1 (1966) 525-8. http://www.ncbi.nlm.nih.gov/pubmed/5908595. 
[25] D.A. Quadrani, H.A. Spiller, D. Steinhorn, A fatal case of gun blue ingestion in a toddler, Vet. Hum. Toxicol. 42 (2000) 96-8. http://www.ncbi.nlm.nih.gov/pubmed/10750175.

[26] S. Normann, K. Nisbet, A.S. Manoguerra, Acute Selenious Acid Poisoning - Case Report, in: Vet. Hum. Toxicol. 26, 1984: p. A-40.

[27] A.J. Nantel, M. Brown, P. Dery, M. Lefebvre, Acute poisoning by selenious acid, Vet. Hum. Toxicol. 27 (1985) 531-3. http://www.ncbi.nlm.nih.gov/pubmed/4082470.

[28] R. Wietecha-Posłuszny, T. Lech, P. Kościelniak, Application of three spectrometric methods to total selenium determination in postmortem material in a case of acute selenium compound poisoning, J. Forensic Sci. 56 (2011) 518-521. https://doi.org/10.1111/j.15564029.2010.01660.x.

[29] T. Lech, Suicide by sodium tetraoxoselenate(VI) poisoning, Forensic Sci. Int. 130 (2002) 448. http://www.ncbi.nlm.nih.gov/pubmed/12427449.

[30] H.A. Spiller, E. Pfiefer, Two fatal cases of selenium toxicity, Forensic Sci. Int. 171 (2007) 6772. https://doi.org/10.1016/j.forsciint.2006.06.077.

[31] A. Gasmi, R. Garnier, M. Galliot-Guilley, C. Gaudillat, B. Quartenoud, A. Buisine, D. Djebbar, Acute selenium poisoning, Vet. Hum. Toxicol. 39 (1997) 304-308.

[32] P. Kamble, N. Mohsin, A. Jha, A. Date, A. Upadhaya, E. Mohammad, M. Khalil, A. Pakkyara, M. Budruddin, Selenium intoxication with selenite broth resulting in acute renal failure and severe gastritis, Saudi J. Kidney Dis. Transpl. 20 (2009) 106-111.

[33] L. Sioris, K. Guthrie, P. Pentel, Acute Selenium Poisoning, in: Vet. Hum. Toxicol., 1980: pp. $22,364$.

[34] I.D.S. Civil, M.J.A. McDonald, Acute selenium poisoning: Case report, N. Z. Med. J. 87 
(1978) 354-356.

[35] Y. Kise, S. Yoshimura, K. Akieda, K. Umezawa, K.I. Okada, N. Yoshitake, H. Shiramizu, I. Yamamoto, S. Inokuchi, Acute oral selenium intoxication with ten times the lethal dose resulting in deep gastric ulcer, J. Emerg. Med. 26 (2004) 183-187. https://doi.org/10.1016/j.jemermed.2003.07.002.

[36] I. Lombeck, H. Menzel, D. Frosch, Acute selenium poisoning of a 2-year-old child, Eur. J. Pediatr. 146 (1987) 308-312. https://doi.org/10.1007/BF00716483.

[37] B. Schuh, U. Jappe, Selenium intoxication: undesirable effect of a fasting cure, Br. J. Dermatol. $156(2007) 163-201$.

[38] D. Müller, H. Desel, Acute selenium poisoning by paradise nuts (Lecythis ollaria), Hum. Exp. Toxicol. 29 (2010) 431-434. https://doi.org/10.1177/0960327109360046.

[39] SCF, Tolerable Upper Intake Levels for Vitamins and Minerals, Scientific Committee on Food Scientific Panel on Dietetic Products, Nutrition and Allergies, 2006.

[40] Institute of Medicine, Dietary Reference Intakes for Vitamin C, Vitamin E, Selenium , and Carotenoids, 2000. http://www.nal.usda.gov/fnic/DRI//DRI_Vitamin_C/vitamin_C_full_report.pdf. 